\title{
Synthesis and Properties of Polymers Based on Styrene and $\alpha$-angelicalactone
}

\author{
Konstantin L. Kaigorodov ${ }^{\mathrm{a}}$, \\ Valery E. Tarabanko*a, Sergei R. Loskutov'b, \\ Elena V. Mazurova ${ }^{a}$, Alexander A. Kondrasenko ${ }^{a}$, \\ Vasiliy D. Voronchikhin ${ }^{c}$, Marina A. Smirnova ${ }^{a}$, \\ Yuri N. Malyar ${ }^{\mathrm{a}, \mathrm{d}}$ and Dmitry O. Vigul ${ }^{\mathrm{a}}$ \\ anstitute of Chemistry and Chemical Technology SB RAS \\ FRC «Krasnoyarsk Science Center SB RAS» \\ Krasnoyarsk, Russian Federation \\ ${ }^{b}$ Sukachev Institute of Forest SB RAS \\ Krasnoyarsk, Russian Federation \\ ${ }^{c}$ Reshetnev Siberian State University \\ of Science and Technology \\ Krasnoyarsk, Russian Federation \\ ${ }^{d}$ Siberian Federal University \\ Krasnoyarsk, Russian Federation
}

Received 20.10.2021, received in revised form 11.01.2022, accepted 13.01.2022

\begin{abstract}
Polyangelicalactone-graft-polystyrene copolymers were obtained through cationic polymerization. Increasing the portion of styrene units in the copolymers improves the strength properties and increases fragility. Increasing the polyangelicalactone(PAL) content in the copolymers increases the elasticity of the materials obtained. The obtained copolymers are greatly a composition of PAL and polystyrene (PS)with a small content of bonds of styrene-units of 4-alkoxypent-3-enoic acid.Low $\alpha$ angelicalactone(AL) content in styrene copolymers improves the oxidative stability of the copolymers. The resulting PAL-graft-PScopolymers have physical and mechanical properties corresponding to the requirements for general-purpose PS.
\end{abstract}

Keywords: copolymerization, polystyrene, $\alpha$-angelicalactone, polyangelicalactone, poly[oxidiyl(4-methyl-1oxobut-3-en-1,4-diyl)], poly[oxidiyl(4-methyl-1-oxobut-3-en-1,4-diyl)]-graft-poly(1-phenylethylene).

(C) Siberian Federal University. All rights reserved

This work is licensed under a Creative Commons Attribution-NonCommercial 4.0 International License (CC BY-NC 4.0).

* Corresponding author E-mail address: veta@icct.ru 
Acknowledgements. This work was carried out within the framework of the budget project № 02872021-0017 for Institute of Chemistry and Chemical Technology SB RAS and was funded by Russian Foundation for Basic Research, Government of the Krasnoyarsk Territory, and the Krasnoyarsk Regional Fund of Science, grant number 18-43-240003, using the equipment of Krasnoyarsk Regional Research Equipment Centre of SB RAS.

\title{
Синтез и свойства полимеров
}

\section{на основе стирола и $\alpha$-ангеликалактона}

\author{
К. Л. Кайгородов ${ }^{a}$, В.Е. Тарабанько \\ Е. В. Мазурова ${ }^{a}$, А. А. Кондрасенко ${ }^{\text {a }, ~ В . ~ Д . ~ В о р о н ч и х и н ~}{ }^{\text {, }}$ \\ М.А. Смирнова ${ }^{\text {a }}$ Ю.Н. Маляр ${ }^{\mathrm{a}, \text { г }, ~ Д . О . ~ В и г у л ь ~}{ }^{\mathrm{a}}$ \\ ${ }^{a}$ Институт химии и химической технологии СО РАН \\ ФИЦ «Красноярский научный центр СО РАН», \\ Российская Федераиия, Красноярск \\ ${ }^{6}$ Институт леса им. В. Н. Сукачева СО РАН \\ Российская Федеращия, Красноярск \\ ${ }^{8}$ Сибирский государственный университет \\ науки и технологии им. М. Ф. Решетнева \\ Российская Федерачия, Красноярск \\ ${ }^{2}$ Сибирский федеральный университет \\ Российская Федераиия, Красноярск
}

\begin{abstract}
Аннотация. Методом катионной полимеризации получены сополимеры полиангеликалактона(PAL) с привитым полистиролом (PS). Увеличение доли стирольных звеньев улучшило прочностные свойства и повысило хрупкость сополимеров, а увеличение содержания PAL повысило их эластичность. Полученные материалы представляют собой композицию PAL и PS с небольшим содержанием связей стирол-звено 4-алкоксипент-3-еновой кислоты и обладают физико-механическими свойствами, соответствующими требованиям, предъявляемым к полистиролу общего назначения. Небольшое содержание $\alpha$-ангеликалактона в сополимерах стирола улучшает их окислительную стабильность.
\end{abstract}

Ключевые слова: сополимеризация; полистирол; ангеликалактон; полиангеликалактон; поли [оксидил (4-метил-1-оксобут-3-ен-1,4-диил)]; поли [оксидил (4-метил-1-оксобут-3-ен-1,4-диил)]прив-поли(1-фенилэтилен). 
Благодарности. Эта работа была выполнена в рамках бюджетного проекта № 0287-2021-0017 для Института химии и химической технологии СО РАН и финансировалась Российским фондом фундаментальных исследований, Правительством Красноярского края и Красноярским региональным фондом науки, грант № 18-43-240003, с использованием оборудования Красноярского регионального центра исследовательского оборудования СО РАН.

Цитирование: Кайгородов, К. Л. Синтез и свойства полимеров на основе стирола и $\alpha$-ангеликалактона / К. Л. Кайгородов, В.Е. Тарабанько, С.Р. Лоскутов и др. // Журн. Сиб. федер. ун-та. Химия, 2022, 15(1). С. 5-13. DOI: 10.17516/1998-2836-0266

\section{Introduction}

An urgent problem of modern civilization is determining how to give polymer materials the ability to biodegrade into safe, nontoxic compounds in the environment [1-4]. One method is to obtain copolymers with monomers or polymers that have this ability.

One new biodegradable polymer is polyangelicalactone (poly[oxidiyl(4-methyl-1oxobut-3-en-1,4-diyl)], PAL), a product of the anionic polymerization of $\alpha$-angelicalactone(5methylfuran-2(3H)-one, AL). AL (lactone of levulinic acid) is obtained from renewable raw materials, fructose, cellulose, and other carbohydrates. The most interesting reactions are the polymerization of AL with opening of the lactone ring, which occurs in the presence of sodium hydroxide, sodium butylate [5,6], and stannous octoate $\left(\mathrm{Sn}(\mathrm{Oct})_{2}\right)$ [7]. The products of such reactions have the ability to biodegrade [5-9].

Saturated five-membered lactones are not usually subjected to ring-opening polymerization (ROP) [13], but a double bond in the cycle can activate this polymerization. Therefore, opening the lactone cycle to form polyester is allowed by thermodynamics [10,11].

Low-molecular PAL samples $\left(\mathrm{M}_{\mathrm{w}} 800-1100\right)$ undergo almost complete biodegradation via the microorganisms Candida parapsilosis and Saccharomyces cerevisiae within 5-15 days and through Streptomyces lividans and Streptomyces anulatus within 20-30 days [5,6].

Polystyrene (PS) is a large-scale industrial polymer. It is widely used, for example, to manufacture disposable tableware. This increases the amount of polymeric waste dispersed throughout the environment [1]. The problem of environmental pollution caused by these wastes can be solved by producing biodegradable modifications of polystyrene[12-15].

Copolymers with molecular weights of 200,000-500,000 were obtained through the reaction of melted PAL with styrene (1-5 mol\%) in the presence of boron trifluoride diethyl etherate as a catalyst. Such copolymers underwent complete biodegradation in gray forest soil in 140 days [9]. The emulsion polymerization of PAL with styrene was also carried out. High-impact biodegradable block copolymers $\left(\mathrm{M}_{\mathrm{w}} 40,000-1,000,000\right)$ containing 5-40 wt.\% of styrene were prepared [16].

The goal of this work is to study the synthesis and properties of polyangelicalactone-graft-polystyrene (PAL-graft-PS) with a wide range of compositions.

\section{Experimental part}

AL (Alfa Aesar, $98 \%$ ) was purified before use via fractional melt crystallization. The styrene («Khimreaktivsnab», «Pure», $1 \%$ of hydroquinone) was washed sequentially once with an aqueous solution of $\mathrm{NaOH}(5 \mathrm{wt} \%)$ and four times with water, dried over anhydrous sodium sulfate, and then 
distilled in a vacuum. The aluminiumisopropoxide was obtained according to the method in [17]. Tetrahydrofuran (THF) («Khimreaktivsnab», «Pure») was washed with a saturated aqueous solution of $\mathrm{NaOH}$, distilled in a vacuum, purified by prolonged reflux in the presence of sodium metal with the addition of benzophenone $(0,2-0,3 \mathrm{wt} \%)$ under the flow of purified argon, and then distilled in a vacuum. Methylene chloride was refluxed in presence of sodium metal, and then distilled in a vacuum. Boron trifluoride etherate $\left(\mathrm{BF}_{3} \mathrm{OEt}_{2}\right)$ was distilled under reduced pressure. Other chemicals were used as received.

PAL was obtained via ring opening polymerization in a solution in tetrahydrofuran in the presence of aluminiumisopropoxide and benzophenoneketyl-Na. In total, $100 \mathrm{~mL}$ of carefully dried tetrahydrofuran, $0,06 \mathrm{~g}$ of benzophenone, and 0,01 $\mathrm{g}$ of metallic sodium (small scales) were placed in a $0,25 \mathrm{~L}$ flask with a reflux condenser. After the formation of benzophenoneketyl-Na, 0,6 $\mathrm{g}$ of aluminiumisopropoxide was loaded into a flask under an argon flow. Then, $10 \mathrm{~g}$ of AL was loaded into the system. The duration of polymerization was 60 minutes at reflux. After cooling obtained polymer was precipitated by ethanol and washed decantation with several portions of cold diethyl ether, and freed of volatile matter by heating at $80^{\circ} \mathrm{C}$ and 2 Torr during one and half hours. There remained 7,6 $\mathrm{g}$ of a slightly yellow solid. THF/ethanol system was used to fractionation of products. For this study, PAL with $\mathrm{M}_{\mathrm{w}} \sim 6000 \mathrm{~g} \times \mathrm{mol}^{-1}$ was used.

Cationic styrene (St) polymerization, and polyangelicalactone grafting with styrene was performed in the presence of boron trifluorideetherate as the catalyst. The boron trifluoride etherate as well the solution of the calculated amounts of the styrene and polyangelicalactone in methylene chloride were thermostated at $-16--18{ }^{\circ} \mathrm{C}$ for 30 minutes before mixing. The monomers solution was placed into the glass tube, and then $\mathrm{BF}_{3} \cdot \mathrm{OEt}_{2}$ was added. After a predetermined time, ice-cold ethanol was added, and then volatile products were evaporated. The removal of unreacted monomers from the precipitated crude product was carried out via extraction in ethanol for 8 hours, followed by dissolution and reprecipitation in the THF/ethanol system.

The molecular weights were defined using the gel permeation chromatography (GPC) method. For chromatographic measurements, the samples were dissolved in the mobile phase $(\sim 5 \mathrm{mg} / \mathrm{ml})$ and filtered through a $0,22 \mu \mathrm{m}$ PTFE membrane filter. The GPC measurements were made using an Agilent 1260 Infinity II Multi-Detector GPC/SEC System chromatograph with triple detection: by a refractometer, by a viscometer and by a light scattering. Separation were made on PlGel Mixed-E and PlGel Mixed-B columns using THF stabilized by $250 \mathrm{ppm}$ BHT as the mobile phase, the flow rate of the eluent was $1 \mathrm{ml} / \mathrm{min}$. All columns were calibrated using polydisperse polystyrene standards (Agilent, USA).

The breaking stress, yield strength, and elongation at break were determined using the tensile machine ZMGi-250 by the standard plastics tensile test methods at a test temperature of $20 \pm 2{ }^{\circ} \mathrm{C}$. The brittleness temperatures were determined using the device for measuring the brittleness of plastics PHP-3.Water absorption was determined by increasing the weight of the polymer specimens immersed in distilled water for 24 hours at $21 \pm 2{ }^{\circ} \mathrm{C}$.

The ${ }^{1} \mathrm{H}$ NMR spectra were measured using a BrukerAvance III 600 spectrometer at $300 \mathrm{~K}$.

Thermogravimetrical analysis was carried in a corundum crucible using an STA 449 F1 Jupiter instrument (NETZSCH) in a temperature range from 30 to $800^{\circ} \mathrm{C}$ in an argon/air flow (the flow rates of shielding and purge gases were 20 and $50 \mathrm{~mL} / \mathrm{min}$, respectively). 


\section{Results and discussion}

The copolymers were synthesized according to scheme (Fig. 1).

Samples were prepared by changing the molar ratio of PAL to St, maintaining the molar ratio $\mathrm{BF}_{3} \mathrm{OEt}_{2} / \mathrm{St}=0,02$, as shown in Table 1 .

The yield of the resulting copolymers was reduced from $87 \%$ to $74 \%$ by increasing the concentration of PAL in the reaction mass from 2 to $98 \mathrm{~mol} \%$. The molecular weight of polystyrene obtained under the studied conditions was 125,000 . The molecular weights of copolymers decreased to 14300 by increasing the PAL content in the polymers.

The systematic decrease in the molecular weights of copolymers by increasing the content of PAL indicates a break in the polymerization chains of relatively inactive olefin fragments of PAL.

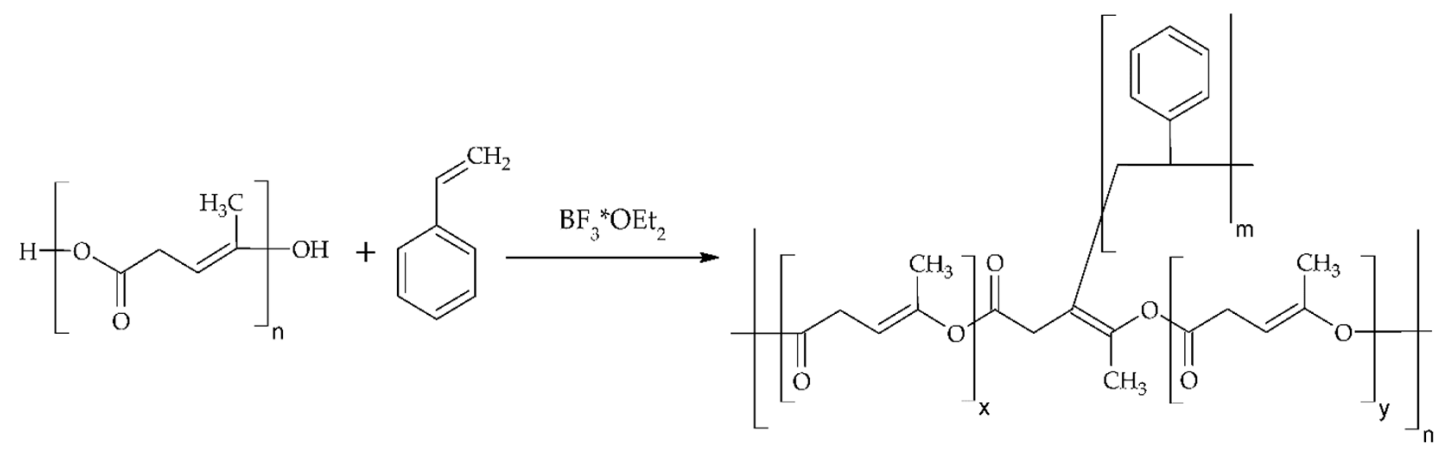

Fig. 1. Scheme of polystyrene grafting of polyangelicalactone

Table 1. The influence of the composition of PAL and St mixtures on the yield, molar masses and polydispersities of the resulting PAL-g-PS copolymers

\begin{tabular}{|c|c|c|c|c|c|}
\hline Sample & $\begin{array}{c}\text { PAL, } \\
\mathrm{mmol}\end{array}$ & $\begin{array}{c}\text { St, } \\
\mathrm{mmol}\end{array}$ & $\begin{array}{c}\text { Polymer yield, } \\
\mathrm{wt} \%\end{array}$ & $\begin{array}{c}\mathrm{M}_{\mathrm{w}}( \pm 6 \%), \\
\mathrm{g} \mathrm{mol}^{-1}\end{array}$ & $\begin{array}{c}\text { PDI } \\
\left(\mathrm{M}_{\mathrm{w}} / \mathrm{M}_{\mathrm{n}}\right)\end{array}$ \\
\hline PAL-g-PS [2:98] & 2 & 98 & 87 & 132800 & 2,19 \\
\hline PAL-g-PS [3:97] & 3 & 97 & 84 & 115700 & 2,45 \\
\hline PAL-g-PS [5:95] & 5 & 95 & 84 & 90000 & 1,98 \\
\hline PAL-g-PS [10:90] & 10 & 90 & 84 & 80800 & 1,96 \\
\hline PAL-g-PS [20:80] & 20 & 80 & 84 & 76300 & 2,00 \\
\hline PAL-g-PS [30:70] & 30 & 70 & 84 & 64300 & 2,04 \\
\hline PAL-g-PS [40:60] & 40 & 60 & 86 & 60800 & 2,02 \\
\hline PAL-g-PS [50:50] & 50 & 50 & 86 & 52100 & 2,19 \\
\hline PAL-g-PS [60:40] & 60 & 40 & 83 & 48200 & 2,32 \\
\hline PAL-g-PS [70:30] & 70 & 30 & 84 & 33000 & 2,34 \\
\hline PAL-g-PS [80:20] & 80 & 20 & 80 & 22600 & 2,27 \\
\hline PAL-g-PS [90:10] & 90 & 10 & 80 & 17400 & 2,15 \\
\hline PAL-g-PS [95:5] & 95 & 5 & 76 & 16900 & 2,16 \\
\hline PAL-g-PS [97:3] & 97 & 3 & 78 & 14800 & 2,00 \\
\hline PAL-g-PS [98:2] & 98 & 2 & 74 & 14300 & 2,12 \\
\hline
\end{tabular}


However, the interaction of high-molecular PAL $\left(\mathrm{M}_{\mathrm{w}} 15,000-19,000\right)$ with St of low concentrations ( $1 \%-5 \%)$ led to an increase in the molecular weight of the copolymer by an order of magnitude, up to $\mathrm{M}_{\mathrm{w}}$ 200,000-500,000 [6]. This means that small styrene additives can initiate the grafting of PAL with the formation of net structures.

\section{NMR study of polymers}

The formation of the synthesized PAL, PS and PAL-g-PS was confirmed by ${ }^{1} \mathrm{H}$ NMR spectroscopy. Figure 2 shows the ${ }^{1} \mathrm{H}$ NMR spectra of the PAL, PS and the PAL-g-PS [40:60] copolymer.

Comparing three spectra shows, that the copolymer spectrum is mainly superposition of homopolymers spectra (a) and (b). This means that the copolymer obtained is greatly a composition of PAL and PS.

Nevertheless, the spectra of products of water-alkaline hydrolysis of the copolymers contained mostly signals of levulinic acid as well as small peaks of protons of the phenyl group (about $1 \%$ ). We assume that the styrene fragments passed into the aqueous phase in the form of water-soluble hydrophilic compounds as a result of copolymerization with double bonds of the ester units of 4-alkoxypent-3-enoic acid.

\section{Physical and chemical properties of polymers}

The physical and mechanical characteristics of the studied copolymers are presented in Table 2. When passing from polystyrene to polyangelicalactone, the tensile strength was reduced by half, the yield strength was reduced by one and a half times, and the elongation at break increased by two

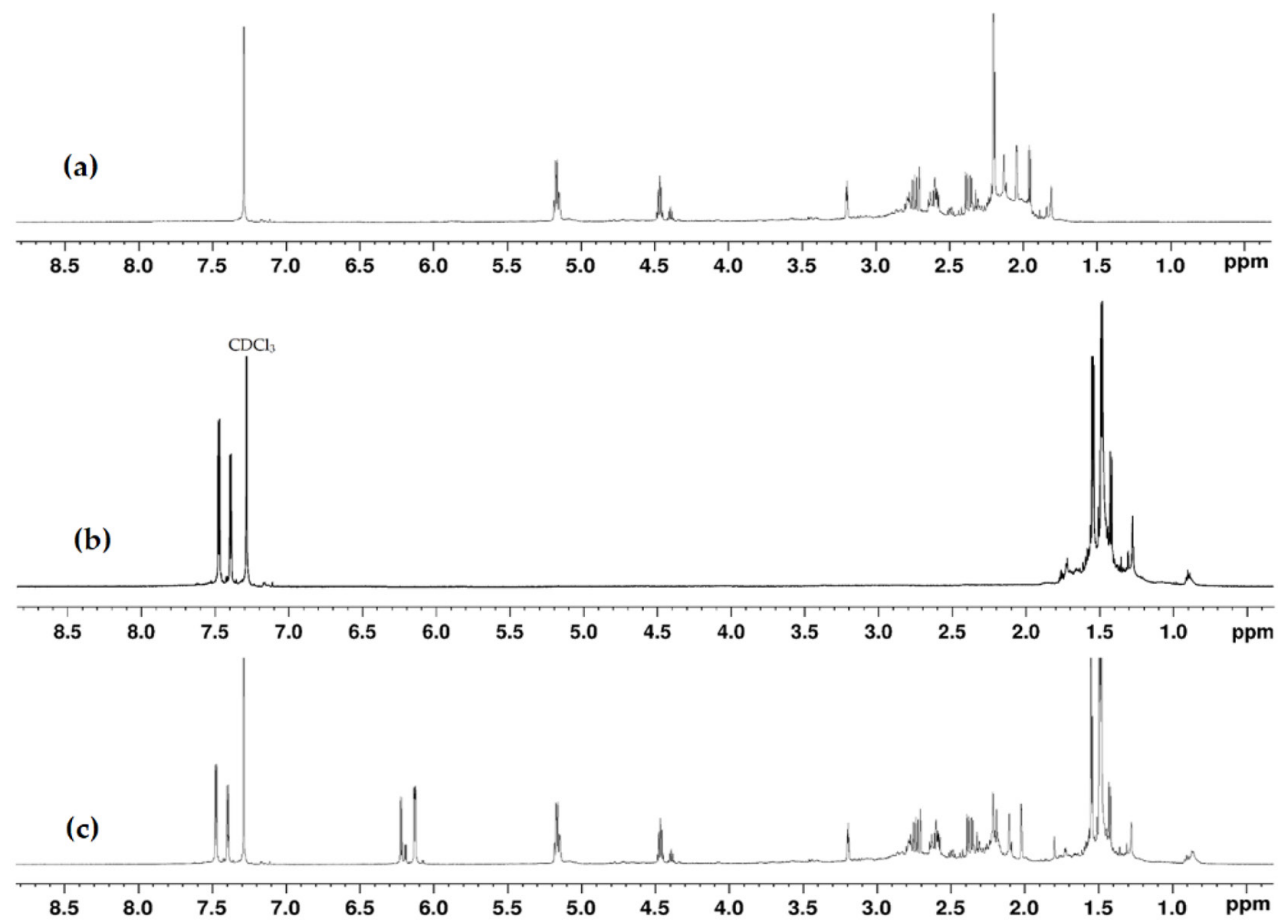

Fig. 2. ${ }^{1} \mathrm{H}$ NMR spectra of the PAL (a), PS (b) and the PAL-g-PS [40:60] (c) copolymer

$$
-10-
$$


Table 2. Physical and mechanical characteristics of obtained PS, PAL-g-PS, and PAL polymers

\begin{tabular}{|c|c|c|c|c|}
\hline Sample & $\begin{array}{c}\text { Ultimate tensile } \\
\text { strength, } \\
\mathrm{MPa}( \pm 4)\end{array}$ & $\begin{array}{c}\text { Elongation at break, } \\
\%( \pm 7 \%)\end{array}$ & $\begin{array}{c}\text { Yield strength, } \\
\mathrm{MPa}( \pm 4)\end{array}$ & $\begin{array}{c}\text { Water absorption, } \\
\%( \pm 4 \%)\end{array}$ \\
\hline PS & 38 & 1,23 & 29 & 0,4 \\
\hline PAL-g-PS [20:80] & 37 & 12,5 & 26 & 0,48 \\
\hline PAL-g-PS [40:60] & 33 & 120 & 20 & 0,58 \\
\hline PAL-g-PS [60:40] & 28 & 490 & 21 & 0,72 \\
\hline PAL-g-PS [80:20] & 23 & 608 & 20 & 1,23 \\
\hline PAL & 21 & 625 & 18 & 1,82 \\
\hline
\end{tabular}

orders of magnitude. Water absorption of the obtained copolymers increased from $0.4 \%$ to $1.82 \%$ for copolymers of PAL with a decrease in the styrene content. The brittleness temperature of the resulting polymers was in the range of -38 to $-48{ }^{\circ} \mathrm{C}$ and increased by increasing the content of PAL in the copolymers.

Thus, an increase in the content of PAL in the initial mixture led to an increase in the flexibility of the macromolecules of the copolymers, which affected the softening temperature and physical and mechanical properties of the synthesized polymers. In addition, the presence of a polyester fragment in the structure of the copolymer causes the formation of adhesive properties. Polystyrene had the greatest strength, and PAL provided the best elastic properties. These characteristics for copolymers smoothly changed according to the composition. Notably, under low PAL contents $(0 \%-20 \%)$, the decrease in the strength indicators and increase in the water absorption of the copolymers were less than $10 \%$.

\section{Thermochemical study of polymers}

The results for the differential thermogravimetrical analysis of the obtained polymers are presented in Fig. 3.
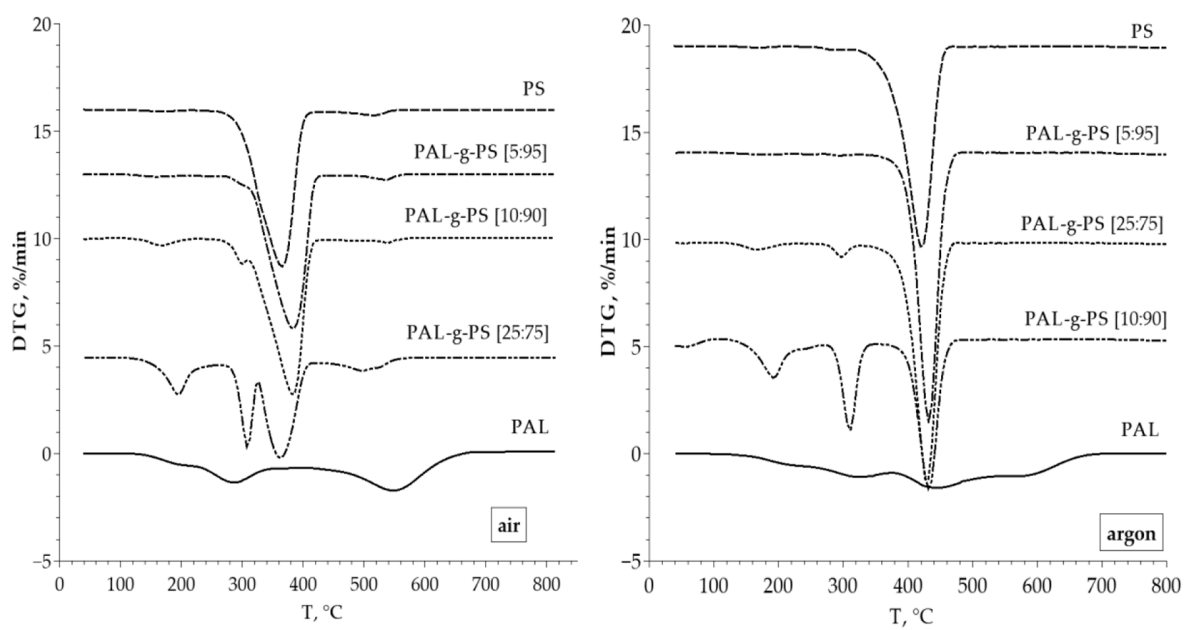

Fig. 3. Differential thermogravimetrical curves of the PAL-g-PS copolymers 
In an argon atmosphere, pure polystyrene began to decompose, with weight loss observed at $300{ }^{\circ} \mathrm{C}$ and the maximum decomposition rate occurring at $409{ }^{\circ} \mathrm{C}$. Styrene and AL copolymers exhibited two additional maximum mass loss rates at 220 and $295^{\circ} \mathrm{C}$.

In the air atmosphere, the maximum weight loss rate of the pure polystyrene sample was shifted by 55 degrees to the low temperature range down to $354^{\circ} \mathrm{C}$, and the temperature of this maximum was practically independent of the PAL content in the copolymer. The position of the maximum at $295{ }^{\circ} \mathrm{C}$ was practically independent of both the PAL content and the composition of the gas phase. The latter indicates oxidative processes with a loss of polymer mass beginning at higher temperatures. These results show that small additions of polyangelicalactone to polystyrene can improve the oxidative stability of the copolymer without changing its heat resistance.

\section{Conclusions}

Series of polyangelicalactone-graft-polystyrene copolymers were obtained through cationic polymerization. Increasing the portion of St units in the copolymers improved the strength properties and increased fragility. Increasing the PAL content in the copolymers increased the elasticity of the materials obtained.

The ${ }^{1} \mathrm{H}$ NMR study shows that the copolymer spectrum is mainly superposition of the homopolymer corresponding spectra. This means that the copolymer obtained is greatly a composition of PAL and PS. Nevertheless, the spectra of products of water-alkaline hydrolysis of the copolymers contained mostly signals of levulinic acid as well as small peaks of protons of the phenyl group (about $1 \%$ ). We assume that the styrene fragments passed into the aqueous phase in the form of watersoluble hydrophilic compounds as a result of copolymerization with double bonds of the ester units of 4-alkoxypent-3-enoic acid.

According to the thermogravimetrical data, styrene copolymers with low AL content up to $5 \%$ did not practically lose their thermal resistance in the inert atmosphere compared to the homopolymer. Moreover, small additions of angelicalactone to polystyrene improved the oxidative stability of the copolymers.

Thus, the resulting polyangelicalactone-graft-polystyrene copolymers have physical and mechanical properties corresponding to the requirements for general-purpose polystyrene. Probably, the copolymers are biodegradable, and a corresponding study is in progress.

\section{References}

1. Suwanmanee, U., Mungcharoen, Th., Leejarkpai, Th. Comparative assessment of global warming impact and eco-efficiency of PS, PET and PLA boxes. J. of Cleaner Production. 2016. Vol. 125. P. 95-107. DOI: 10.1016/j.jclepro.2016.03.029.

2. Scott, G. Degradable Polymers. Principles and Application. 2nd ed. Springer, Netherlands: Dordrecht, Netherlands, 2002. P. 1-15.

3. Hu, H., Liu, J.-F., Li, C.-Y., Yang, S.-Z., Gu, J.-D., Mu, B.-Z. Anaerobic biodegradation of partially hydrolyzed polyacrylamide in long-term methanogenic enrichment cultures from production water of oil reservoirs. Biodegradation. 2018. Vol. 29. P. 233-243. DOI:10.1007/s10532-018-9825-1.

4. Ding, M., Zhang, M., Yang, J., Qiu, J. Study on the enzymatic degradation of PBS and its alcohol acid modified copolymer. Biodegradation. 2011. Vol. 23. P. 127-132. DOI: 10.1007/s10532-011-9492-y. 
5. Tarabanko, V.E., Kaygorodov, K.L., Sokolenko, V.A., Chernyak, M. Yu. Issledovaniye polimerizatsi i a-angelikalaktona [The Study of $\alpha$-Angelicalactone Polymerization]. Khimiia rastitel'nogo syr'ia. 2006. № . 2. P. 37-41 (In Russ.).

6. Tarabanko, V.E., Kaygorodov, K. L. New biodegradable polymers based on $\alpha$-angelicalactone. Chem. for Sustainable Development. 2010. Vol. 3. P. 395-403.

7. Chen, T., Qin, Z., Qi, Y., Deng, T., Ge, X., Wang, J., Hou, X. Degradable polymers from ringopening polymerization of $\alpha$-angelica lactone, a five-membered unsaturated lactone. Polymer Chem. 2011. Vol. 2. P. 1190-1194. DOI: 10.1039/C1PY00067E.

8. Tarabanko, V.E., Kaygorodov, K.L. New Environmentally Benign Polymers Produced by Copolymerization with $\alpha$-Angelicalactone. Macromolecular Symposia. 2015. Vol. 354. P. 367-373. DOI: 10.1002/masy.201400108.

9. Tarabanko, V.E., Kaygorodov, K.L., Chernyak, M. Yu. Polyesterification of alphaAngelicalactone. J. Sib. Fed. Univ. Chem. 2008. Vol. 1(1). P. 118-123.

10. Lebedev, B.V. Thermodynamics of Polylactones. Russian Chem. Reviews. 1996. Vol. 65. P. 1063-1082. (In Russ.). DOI: 10.1070/RC1996v065n12ABEH000246.

11. Kaygorodov, K.L., Tarabanko, V.E., Tarabanko, N. Thermodynamics of $\alpha$-angelicalactone polymerization. Cogent Chem. 2018. Vol. 4(1). P. 1443689. DOI: 10.1080/23312009.2018.1443689.

12. Ho, B.T., Roberts, T.K., Lucas, S. An overview on biodegradation of polystyrene and modified polystyrene: the microbial approach. Critical Reviews in Biotechnology. 2018. Vol. 38(2). P. 308-320. DOI: $10.1080 / 07388551.2017 .1355293$.

13. Leluk, K., Hanus-Lorenz, B., Rybak, J., Bozek, M. The effectiveness of the biodegradation of raw and processed polystyrene by mealworms. E3S Web of Conferences. 2017. Vol. 22. P. 0-7. DOI: 10.1051/e3sconf/20172200103.

14. Yang, S.S., Wu, W.M., Brandon, A.M., Fan, H.Q., Receveur, J.P., Li, Y., Wang, Z.Y., Fan, R., McClellan, R.L., Gao, S.H., Ning, D., Phillips, D.H., Peng, B.Y., Wang, H., Cai, S.Y., Li, P., Cai, W.W., Ding, L.Y., Yang, J., Criddle, C. S. Ubiquity of polystyrene digestion and biodegradation within yellow mealworms, larvae of Tenebriomolitor Linnaeus (Coleoptera: Tenebrionidae). Chemosphere. 2018. Vol. 212. P. 262-271. DOI: 10.1016/j.chemosphere.2018.08.078.

15. Tsochatzis, E., Lopes, J. A., Gika, H., \& Theodoridis, G. Polystyrene biodegradation by tenebriomolitor larvae: Identification of generated substances using a gc-ms untargeted screening method. Polymers. 2012. Vol. 23(1). P. 1-12. https://doi.org/10.3390/polym13010017.

16. Kaygorodov, K.L., Tarabanko, V.E., Smirnova, M.A., Tarabanko, N., Malyar, Yu.N., Voronchikhin, V.D. Emulsion copolymerization of polyangelicalactone with styrene. J. Sib. Fed. Univ. Chem. 2019. Vol. 12(2). P. 261-268. DOI: 10.17516/1998-2836-0124.

17. Khosravi, M., Andrus, M.B., Burt, S.R., Woodfield, B.F. Generalized preparation method and characterization of aluminum isopropoxide, aluminum phenoxide, and aluminum n-hexyloxide. Polyhedron. 2013. Vol. 62. P. 18. DOI: 10.1016/j.poly.2013.06.019. 